\title{
Zoning for Jobs-Industrial Land Preservation in the Nation's Largest Cities
}

\author{
Jamaal Green
}

June 28, 2017

\section{Introduction}

This study finds an emerging understanding of the strategic importance of protecting existing industrial land in 12 of the country's largest cities. Each city has passed a new set of land-use designations protecting industrial land from conversion to non-industrial uses in order to stem industrial job loss, maintain strategic reserves of a shrinking resource, or to encourage the growth of good jobs that serve a wide array of workers and business owners.

Widening social inequality amidst unprecedented growth poses a fundamental challenge to planners in the nation's largest cities. A major driver of this growing inequality is the loss of "good jobs" at the lower end of the labor market in many cities (Kalleberg 2011; Bernhardt and Osterman 2016). Due to the inability, or unwillingness, of cities and states to pass labor market policies such as mandated leave, living wage ordinances, or hiring supports, economic development planners are left primarily with industrial strategies to grow the number of "good jobs". Unfortunately, the kinds of jobs that do provide good jobs to workers with a wide range of educational attainment- industrial jobs- have the least amount of physical space in cities to operate, and, in many instances, are being actively pushed out by existing land-use policy (Byron and Mistry 2011).

A central conflict in many cities now, then, concerns future uses of industrial land (particularly more centrally located industrial districts that are most attractive to residential and commercial developers). Recent planning scholarship highlights how many city policies actually actively displace industrial users (and by extension the jobs they produce and the workers who fill them) (N. G. Leigh and Hoelzel 2012; Wolf-Powers 2005; Lester, Kaza, and Kirk 2013). In response to this research, and a growing realization by practicing planners that the loss of industrial land is a crisis in many cities, the APA recently released a policy guide offering instructions for cities that wish to grow their industrial workforces (N. Leigh et al. 2014). A consistent message in these studies is that industrial land should be protected and that cities should pass additional protections in 
order to guarantee such lands will be used for jobs production in the future. While these studies highlight the problem of industrial land conversion and offer guidance to address it, no one study has yet done a more systematic survey of already-existing industrial land preservation policies.

In this study, I review the industrial land-use policies of the nation's fifty largest cities (according to their total populations in 2012) in order to see to what extent industry preservation policy is actually used.

My research shows that twelve of the nation's fifty largest cities have some form of industrial preservation policy. These policies generally take one of two approaches: either they add additional use restrictions to selected industrial areas of the city or they impose additional process requirements for conversion.

The paper continues first with a background section exploring the political economic context that encourages cities to convert industrial land, planning's response, or lack thereof, to shrinking industrial land bases, and the importance of industrial land in urban economic development. Next a methodology section describes my identification strategy and a description of the data sources used. The results section offers a brief description of each city's industrial preservation policy classifying each one on the spectrum between adding new use restrictions or intensifying the process necessary to convert parcels from non-industrial uses.

\section{Background}

\section{Local Politics and Planning's Fiscal Imperatives}

The conversion of industrial land in many cities is a direct application of a more entrepreneurial planning approach that prioritizes immediate fiscal concerns over alternative strategic outcomes such as increasing employment or bolstering local innovation. To state the obvious, such conflicts over industrial land are quite political and often pit local neighborhoods and industrial users against real-estate developers and fiscally sensitive planners.

Planners have very real incentives to convert industrial land to non-industrial uses, but there are also ideological and organizational constraints that steer planners towards supporting city-led deindustrialization. For example, WolfPowers (2005) describes the current patterns of industrial land conversion in New York as a response to the need of cities to maximize property tax receipts in the face of decreased federal support starting in the 1970s. But beyond these urgent fiscal constraints Wolf-Powers also identifies how particular modes of planning- specifically an opportunistic and entrepreneurial approach to planningas opposed to more comprehensive ways of planning also encourage the conversion of scarce, yet attractively located, tracts of industrial land. Wolf-Powers contrasts this entrepreneurial mode that explicitly privileges real-estate values with more 
deliberate approaches that explicitly weigh development decisions on a broader array of goals and values.

Beyond organizational constraints, planners' own understanding of their cities' current and future labor market shape industrial land policy. Wolf-Powers identified a clear anti-industrial bias in planners' visions for New York. This bias was informed by the very real and harsh deindustrialization the city suffered due to the rise of global manufacturing competition. This view, though, was preceded by the opinion that all remaining industry was either dying or quickly approaching obsolescence. Planners' alternative vision, then, was one where the city's labor market would specialize even more in tourism and FIRE industries. In their vision of a globally competitive city there was no room, or need, for industrial users and workers. Thus the way that planners envisioned what a future labor market should look like played directly into what Wolf-Powers calls "passive support" for deindustrialization.

While planners may engage in more neglectful policies concerning industrial users, Rast's (Rast 2001) history of post-war development politics in Chicago shows urban deindustrialization to be a deliberate strategy encouraged by downtown coalitions seeking to restructure central cities in their own image and how these patterns of deindustrialization and conversion were countered by the rise of strong neighborhood coalitions looking to protect industrial jobs. In Chicago, then, conflict over industrial land was conflict over the shape of the labor market of the city and who can benefit from it. Both Wolf-Powers and Rast focus on the explicitly local political nature of urban industrial employment and challenge the conventional wisdom of a primarily structural/fiscal explanation of deindustrialization driven by increased competition from abroad and capital flight. But also both cases are about what a city should look like and who can meaningfully thrive in the future.

\section{Smart Growth and Industrial Development}

Beyond their political economic context cities are also encouraged to convert industrial land by policy consensus. The predominate planning policy approach of the past thirty years- Smart Growth- recommends a land-use policy that is, at best, indifferent to industrial land provision and, at worst, actively encourages cities to dispose of their industrial land due to assumed obsolescence and environmental concerns. Leigh and Hoelzel (2012) review Smart Growth manuals and policies across the country and find that Smart Growth policies largely frame industrial land as a drag on local economies and sources of environmental contamination. In response, they note the myriad uses industrial land has in addition to local fiscal priorities and private sector employment including, but not limited to: space for public vehicles and infrastructure such as transit agency garages; limiting further job sprawl and spatial mismatch between workers and job locations; and creating more resilient, innovative local economies by having a true mix of industries present in our cities (N. G. Leigh and Hoelzel 2012). 
Leigh and Hoelzel highlight an emerging policy concern for cities now aware of impending industrial land shortages and a lack of widely accepted policy guidance that more explicitly links land-use with strategic economic concerns that respect the whole labor market. The American Planning Association has stepped into the conceptual and policy gap here offering a guide, published by Leigh and others, called Sustainable Industrial Development that frames industrial land as a strategic asset that must be managed if cities are to maintain operations as well as provide space for economic growth and development (N. Leigh et al. 2014). The guide even offers a chapter on land-use controls and offers a review of zoning tools in New York, Chicago, Philadelphia and Seattle.

\section{Redevelopment and Labor Market Change}

Ultimately, advocates for industrial land preservation assume that the supply of industrial land in cities is good for local economies. But such policies are generally seen as inefficient as they give industrial users an implicit subsidy and prevent intensification on land that could support a greater number of jobs or residences. A series of recent studies challenge the neoclassical view that protecting industrial land stifles growth and development by highlighting the role that available industrial land plays in seeding new businesses and jobs and the local labor market effects of converting industrial land to non-industrial uses.

Chapple (2014), in a study of four cities in the Bay Area of California, estimates the role of industrially zoned land in regional business dynamics, specifically job and firm expansion. Chapple (2014) finds that controlling for site, firm, and neighborhood characteristics, job growth is more positively associated with businesses located in industrially zoned areas than businesses in non-industrially zoned areas. Chapple finds that industrially zoned land seeds greater job and business growth by offering the potential for firms to grow in place as opposed to attracting already mature firms into the region. Also, because Chapple's study uses four Bay Area cities the findings offer strong support for preserving industrial land in strong market cities where demand for industrial land conversion is often the greatest. While Chappel focuses on the regional business dynamics of industrial land, Lester and Hartley (2013) look at local (census tract level) employment change in the face of gentrification. They find that gentrifying tracts had faster job growth but that pre-existing industrial jobs were replaced by less well compensated restaurant and retail work. In their analysis they find find that gentrifying forces are themselves partially responsible for local industrial change. While Lester and Hartley (2013) do not explicitly test zoning, they do highlight the importance of local land-use change as a key driver in urban industrial restructuring, again drawing our attention to local planning dynamics as an important determinant in economic change.

The literature suggests that industrially zoned land plays an important role in greater business dynamics, regional economic resilience, and more equitable local labor market outcomes. Amidst a growing realization of the shortage 
of productive land in central cities more cities are undertaking industrial land supply studies (Dempwolf 2010) and taking industrial land management seriously. But there remain open questions as to what policies cities are currently taking, in particular do we see cities taking advantage of protective zoning similar to Chicago's Planned Manufacturing Districts (Fitzgerald and Leigh 2002) to protect industrial land?

\section{Methodology and Data}

This study is a content and descriptive analysis of land-use policies (both zoning codes and comprehensive plans) ${ }^{1}$ of the US's fifty largest cities, by population, in 2012 according to the US Census Bureau. I collected policies from each city by perusing their latest zoning codes, comprehensive plans and economic development websites. I coded potential industrial preservation policies on two criteria, the first functional and the second more discursive:

1. The code is distinct and protective- The code is in addition to the standard manufacturing zones and lists a stronger set of protections or limitations on uses of the land than is found in the standard codes

2. Industrial Land is an asset- The code does not frame industrial land as a nuisance but as an asset that is important for the local economy/job base

I decided upon identifying separate and distinct policies as recent studies show that cities that do adopt industrial preservation policies often designate protected districts as opposed to increasing protections on all existing manufacturing land (N. G. Leigh and Hoelzel 2012; N. Leigh et al. 2014). Secondly, Green-Leigh and Hoelzel (2012) highlight the importance of discourse surrounding industrial land and moving from a deficit or nuisance frame to one of an asset.

Beyond identifying the codes, I also marked what kinds of additional restrictions were required (residential, commercial, retail, restaurants, healthcare sites, day cares, primary/secondary educational institutions, and public buildings). Additionally, I attempted to code whether or not the listed policy required additional review compared to the standard zoning code and at what levels that review is made. For example, applications for rezoning protected industrial lands in Minneapolis trigger a comprehensive plan amendment process that requires both city and regional review.

An archetypal example of the kind of policy language I looked is the stated purpose of Chicago's Planned Manufacturing District ordinance (City of Chicago 1988):

" 17-6-0401-A Purpose. The "PMD", planned manufacturing district zoning classification is intended to: 1 . foster the city's industrial base;

\footnotetext{
${ }^{1}$ Most of these districts are listed in city zoning codes but a few are listed in their respective city's most recent comprehensive plans such as San Diego's Prime Industrial Lands or as independent policy projects like New York's Industrial Business Zones
} 
2. maintain the city's diversified economy for the general welfare of its citizens; 3 . strengthen existing manufacturing areas that are suitable in size, location and character and which the City Council deems may benefit from designation as a PMD; 4. encourage industrial investment, modernization, and expansion by providing for stable and predictable industrial environments; and 5. help plan and direct programs and initiatives to promote growth and development of the city's industrial employment base."

Chicago's PMD ordinance demonstrates the asset-based view of industrial land well as well as explicitly linking the preservation of industrial land with zoning to greater planning priorities. In terms of use, PMD review requires prospective developers to estimate the impact on surrounding industrial users explicitly in filing for a rezoning as part of the review. This extra layer of review and impact assessment act as an effective barrier to industrial parcel conversion.

In addition to the code review, I noted the year the industrial protective ordinance was passed, if possible, whether or not the city performed an industrial land-use study and the latest year a study was commissioned if a city did and the year in which it was commissioned. In some rare exceptions, regional MPOs conduct such inventories, in cases where this occurred I listed the latest study whether city or regional.

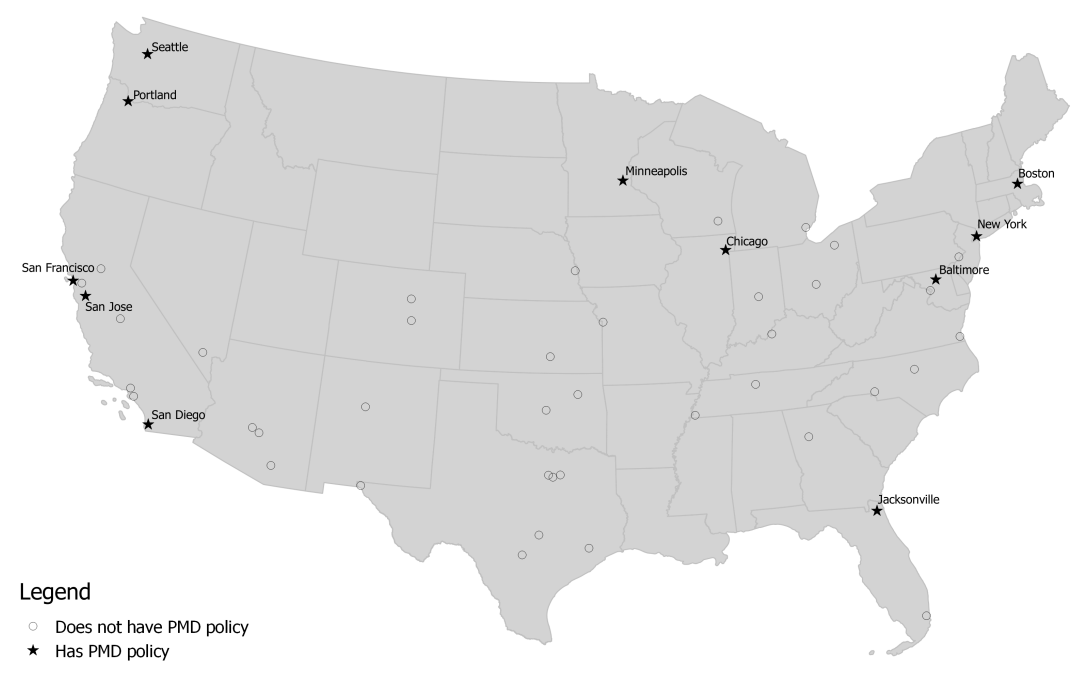

Figure 1: Cities with Industrial Land Protection Policies 


\section{Results}

Industrial land preservation zoning is more common across the nation's largest cities than many would assume based on the coding criteria. Twelve of the nation's largest cities have some variant of industrial preservation/conservation zoning. These eleven cities held eighteen million people in 2012, and while they are geographically dispersed, industrial preservation zoning is concentrated in west coast cities from San Diego to Seattle.

\begin{tabular}{llllll}
\hline City & State & Population, 2012 & Policy Passed & Land Study & Study Year \\
\hline New York & NY & $8,199,221$ & 2005 & Yes & 2014 \\
Chicago & IL & $2,714,856$ & 1988 & Yes & 2004 \\
San Diego & CA & $1,338,348$ & 2008 & Yes & $2009^{*}$ \\
Jacksonville & FL & 836,507 & 2007 & No & - \\
San Francisco & CA & 825,863 & 2008 & Yes & 1998 \\
Boston & MA & 636,479 & 1978 & Yes & 2002 \\
Seattle & WA & 634,535 & 2002 & Yes & 2009 \\
Baltimore & MD & 621,342 & 2004 & Yes & 2015 \\
Portland & OR & 603,106 & 1988 & Yes & 2012 \\
San Jose & CA & 982,765 & 2007 & Yes & 2016 \\
Minneapolis & MN & 392,880 & 2009 & Yes & 2006 \\
\hline
\end{tabular}

Table 1: Cities with Industrial Preservation Policies Note- the inventory was authored by SANDAG, the San Diego region COG

\section{Code Differences}

While each city has their own unique implementation of protective codes their variation can be divided into two broad categories: use restrictions and process rules. Use rules refer to the actual allowed uses listed by the city within the zones of interest. For example, Chicago's Planned Manufacturing Districts (PMDs) have a blanket ban on residential uses, whereas the city's other industrially zoned districts may allow some forms of residential development on a conditional basis. Process rules refer to the necessary steps a developer or property owner must take in applying for a re-zoning in a protected areas. Again using Chicago as an example, for prospective re-zonings of buildings within PMDs the city's Zoning Board of appeals are supposed to take multiple potential impacts into account such as the impact on neighboring industrial users, the current neighborhood job market, and potential local real estate impacts. In this sense, Chicago's PMDs use a combination of both increased use restrictions and multiple additional process requirements. 


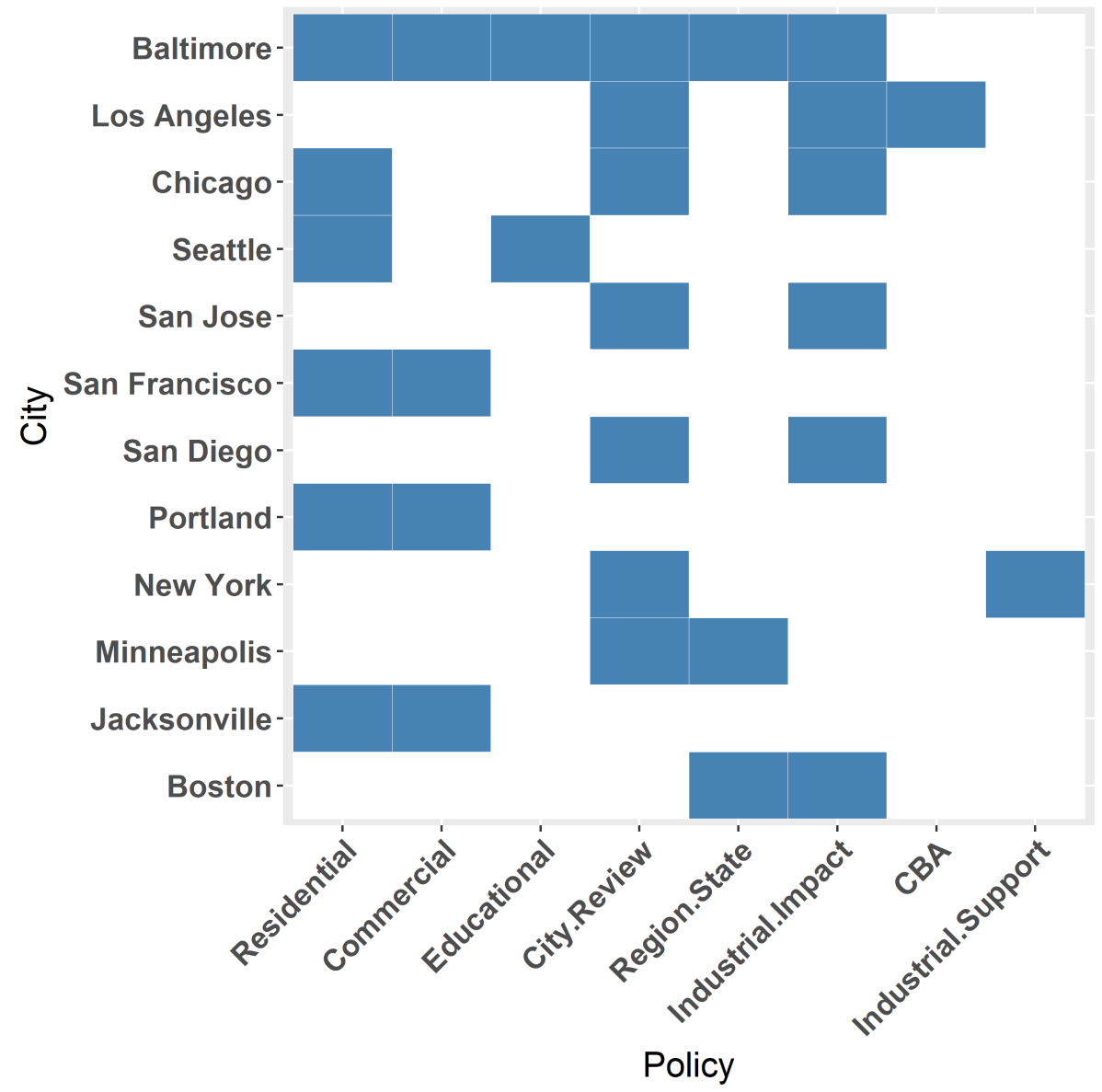

Figure 2: Cities Use Combination of Use Restrictions and Additional Process 


\section{Chicago}

Chicago is probably the archetypal case of industrial land protection in the US. As mentioned above, the city has both stronger use restrictions compared to the city's standard industrial districts, as well as, additional process requirements.

Chicago's PMDs are very restrictive in terms of appropriate uses compared to standard industrial zones in the city. Residential development is banned outright and PMDs, generally, do not allow outdoor agricultural uses or consumer financing establishments. Additional use restrictions exist for particularl PMDs are spelled out in their supplemental use regulations. One example of this is that light equipment sales (boats and motorcycles) is prohibited in ten PMDs and allowed, to varied extents, in the other five.

In terms of process, the city's Zoning Board of Appeals must answer a series of questions regarding the potential impact of a rezoning including, but not necessarily limited to: current industrial uses adjacent to the site and the potential for nuisance complaints if a re-zoning is approved; the current job market in the district and potential jobs impact of the new development, the kinds of jobs currently available in the district; the potential effects of the redevelopment on surrounding property values; traffic impacts; and whether there have been past attempts to market the property to an industrial user.

\section{San Diego}

San Diego's Prime Industrial Lands (PILs) are identified in its latest comprehensive plan, are managed at the community planning level, and depends primarily upon process rules to protect industrial lands. PILs are areas that were already zoned for industrial use and were identified by the city and the responsible planning areas as holding especially vital land and are targeted for protection and expansion of industrial uses. Of particular concern for planners when initially deciding on PILs were identifying locations of strategic importance to the city's large, and growing, logistics and transport industries.

For all proposed developments San Diego requires a lengthy set of impact statements, including but not limited to: traffic; environmental; and health impact studies. Proposed developments in a PIL require an additional impact statement concerning the impact of the development on the availability of prime industrial land supply and as well as the overall industrial employment viability of the PIL were the development approved. Once those impact statements are written they are then submitted to the local community planning area group, if approved, the application is submitted to the city Planning Commission, and, finally, to the City Council for final approval. The result is a rigorous three-stage process that all proposed developments must pass but with the addition of a PIL specific impact statement. 


\section{Baltimore}

Baltimore's Maritime Industrial Districts (MIDs) are designed to protect and maintain deepwater frontage for the Port of Baltimore's industrial uses. MIDs have both much more increased restrictions and additional process requirements compared to the city's other industrial zones.

MIDs are much more restrictive than other industrial districts in the city. MIDs ban all residential uses and even limit multiple institutional uses such as hospitals and certain kinds of schools. Additionally, MIDs do not allow for certain kinds of open space uses like parks and forbids nearly all commercial uses that do not directly support maritime industrial customers. MIDs even prohibit some industrial uses in favor of prioritizing maritime uses explicitly.

Similarly to San Diego, Baltimore also has multiple criteria proposed developments in MIDs must meet in order to be approved (City of Baltimore 2017, 123):

1. The proposed rezoning conforms with the goals of the city's master plan

2. The proposed development would not limit access into or out of the district

3. The development would not encourage or cause the loss of deepwater assets in the district

4. Would not negatively impact adjacent industrial users who must now contend with non-industrial neighbors

5. Would not reduce or impede future economic development and growth of maritime industry within the district

6. Would have an appropriately sized buffer to separate industrial from non-industrial users

7. Adhere to federal rules regarding homeland security and port safety

8. The Maryland Port Administration and adjacent property owners must be notified of the proposed change and the Director of Planning must receive an opinion from the Port Administration at least 30 days before the re-zoning hearing

Baltimore's MIDs are arguably the most restrictive industrial policies in the country banning nearly all non-maritime related uses and requiring both city and state reviews in addition to adhering to federal Homeland Security rules.

\section{Jacksonville}

Jacksonville depends upon more stringent use rules as its primary policy lever. The city has two protective zones- the industrial sanctuary overlay zone and the area of situational compatibility zone. The industrial sanctuary overlay zone is 
the more stringent of the two, but both have more stringent requirements for non-industrial uses than the city's standard industrial zones.

The city's primary zoning tool for these zones is not the outright banning of incompatible uses, such as in Baltimore or Chicago, but through large buffer requirements for proposed non-industrial uses. For example, residential zones in the industrial sanctuary overlay zone, depending on their density, are required to have either a 300 foot buffer (for low density residential development) or a 200 foot buffer for multifamily. Additionally, proposed commercial developments are subject to buffers of 50 and 100 feet for standard commercial areas and commercial-office mixed areas. The area of situational compatibility zone also has buffer requirements but less extreme ones of 100 and 50 feet for single family and multifamily developments.

Beyond the more stringent buffer rules for non-industrial uses, the industrial sanctuary overlay zone allows for more liberal industrial uses than those delineated in other industrial districts in the city.

\section{San Francisco}

San Francisco's Production, Distribution, and Repair (PDR) zones were created in order to address the gaps in the city's traditional manufacturing zones. PDRs have much more stringent use restrictions than the city's traditional manufacturing zones, including an outright ban on residential uses except for homeless shelters given a conditional use exemption. Additionally, PDR zones place additional restrictions on proposed commercial developments.

\section{Portland}

Portland has six "employment" zones, of which three, are specifically industrial oriented: General Industrial 1, General Industrial 2, and Heavy Industrial. While the industrial zones are largely self-explanatory, the other three employment zones also allow for industrial businesses. The three industrial zones make up the greater "industrial sanctuary" for the city. The industrial sanctuary zones have more stringent use restrictions as well as additional policy support for supporting freight movement such as requiring wider streets to accomodate truck traffic.

In terms of its use restrictions, Portland's industrial sanctuary primarily restricts new retail and office development (residential uses are generally not allowed in industrial zones already). The city also forbids most major institutional uses ranging from hospitals and schools to jails in the industrial sanctuary. Though, recently the restrictions on office development were loosened to allow for greater industrial office/support employment.

While the industrial sanctuary rules heavily circumscribe non-industrial uses, the sanctuary also loosens development restrictions for industrial users with no 
height or FAR restrictions for industrial redevelopment.

Finally, the industrial sanctuary zones are also all city-designated "Freight Districts". Such districts have additional requirements on street capacity to allow for easier truck movements through the districts.

\section{Boston}

Boston's industrial sanctuary rules are largely dictate Massachusetts state landuse law. Specifically, the city has waterfront manufacturing (WM) and marine economy reserve (MER) districts designated to support maritime industries. These waterfront districts largely overlap with Massachusetts Designated Port Areas (DPA). The state has 10 DPAs that were designated thanks to the 1978 Coastal Zone Management Act. This act is designed to preserve the state's shoreline for "public use" of which marine-dependent industry is included. DPAs are a recognition that existing environmental regulations and priorities limit the potential to create new, large maritime industrial areas on sensitive shore or wetland areas and thus seeks to protect existing maritime industrial space.

The combination of DPA process rules and Boston's additional restrictions protect existing maritime uses in the city. DPAs are managed at district level covering a wide variety of uses that are all connected to supporting maritime industrial uses. As such, individual parcels are not eligible to either be removed or added to DPAs, only significant portions or entire DPAs can be transitioned. Cities wishing to remove or add areas to their DPAs must take part in an extensive three-part review for the the state along with an additional maritime industrial suitability analysis in order to determine whether the proposed area can be removed from the DPA.

In addition to the state process, Boston's own rules limit retail and restaurant developments within WMDs to no more than 2,500 square feet, generally disallows residential uses and conditionally allows some institutional uses such as museums, daycares, or correctional institutions.

\section{San Jose}

San Jose's Framework for Employment Lands instituted a no-net loss employment lands policy creating a new set of requirements developers must meet if they wish to redevelop industrial parcels (City of San Jose 2007). While the policy references all employment lands, including some commercially zoned land, industrially zoned parcels are given additional consideration under the no loss rule. In order for a proposed re-zoning of industrial employment land to be approved the city offers four ideal characteristics of an offset site:

1. The site is adjacent to viable heavy or light industrial land

2. The site is currently zoned heavy or light industrial 
3. The site currently contains legal industrial businesses

4. The site is at least five acres

In addition to the recommended site features potential developers are also required to contact potentially impacted property owners of the proposed change and to go through the process of a General Plan amendment. The city makes decisions on General Plan Amendments four times a year. Amendment applications must include a full Environmental Impact Review, are presented at community meetings for public discussion, verbally presented to the Planning Commission who will then forward their recommendations to the City Council where a final decision is made.

\section{New York}

New York's "Industrial Business Zones" (IBZs), passed under Mayor Bloomberg, are primarily an industrial attraction and support tool, but the mayor's office reserves the right to deny individual applications seeking to convert parcels to non-industrial uses. Aside from the unilateral power to reject individual applications IBZs are primarily tools for reshaping New York's production landscape through offering a series of subsidies for city businesses to relocate into the IBZs.

Each IBZ is managed by a community and workforce development organization that offers specific programming and policy support for businesses within the IBZ and prospective businesses looking to move into the IBZ. These organizations work with industrial users to take advantage of series of tax supports from the city including, but not limited to: an IBZ business relocation credit that offers $\$ 1,000$ per employee up to $\$ 100,000$; a relocation tax credit for firms looking to move into the city or from certain areas of Manhattan; and jobs training tax credits for innovative industries. Individual IBZ organizations also offer their own individual job training and industrial support programs.

In addition to their supportive subsidies IBZs do have some increased use restrictions. Specifically, hotels will now require a special permit to locate in IBZs and there is an ongoing public comment period weighing increasing restrictions on their construction. Additionally, the city is debating whether to limit the expansion of self-storage facilities and is currently taking public comments on the issue.

IBZs are still evolving as a policy tool but are the most comprehensive in terms of supportive industrial policy while now moving towards harder regulatory approaches to prevent encroachment of non-industrial uses. 


\section{Seattle}

Seattle's most recent comprehensive plan re-states the city's commitment to protecting industrial land in line with King County's regulations regarding Manufacturing/Industrial Centers (MICs). MICs are industrial areas designated by the county to accommodate industrial growth. The city of Seattle has two MICs within its borders and follows the rules set forth by the county. MICs protect industrial land through greater restrictions on uses including greater restrictions on potential commercial and residential development as well as greater restrictions on institutional uses such as primary and secondary schools. In addition to the county restrictions, the city's most recent draft of their comprehensive plan proposes policies and language to further discourage residential conversion and to loosen building height restrictions of industrial buildings in MICs.

\section{Minneapolis}

Minneapolis primarily uses a new stringent redevelopment process to protect its industrial within their newly formed industrial employment districts. The districts are a new overlay designation in the latest comprehensive plan that offers language that the city should prioritize industrial uses/users in the districts as well as steer new industrial development into them.

Converting industrial parcels to non-industrial uses in employment districts now activates a comprehensive plan amendment process where public input is required and the city weighs the question of conversion specifically against the current supply of industrial land and future industrial employment impact. If the City Council approves the amendment, then the city must propose the change to the Metropolitan Council who have the final decision.

\section{Discussion}

Industrial land management is a growing concern for cities and for contemporary planning research. To date, though, there has not been a fuller accounting of the cities that are actively protecting their industrial land and the details on their policies. A major reason for this lack of a review is that active industrial land-use policy is a relatively recent phenomenon in the nation's largest cities. The average year of passing a policy is only 2001 and most of the policies were passed after 2004. Paralleling the observations of Leigh et al (N. Leigh et al. 2014; N. G. Leigh and Hoelzel 2012), these cities realize that their economies, and general management, depend upon an adequate supply of industrial land, and, maybe more importantly, regulatory certainty for industrial users. As an answer most cities rely upon restrictive regulatory policies either directly limiting 
non-industrial uses in industrial districts, adding additional layers of review or some combination therein.

While most of the policies rely wholly upon restricting uses and making conversion harder, a small number of cities offer explicit support to current and potential industrial users. These differences are largely reflective of slightly different goals at the city level incorporating both industrial retention and intra-city industrial relocation goals. NYC IBZs are the most dramatic example of this as they are largely a vehicle for industrial firm support and subsidy with a zoning component attached to it. Seattle and Minneapolis are also taking a more proactive approach to helping industrial users in their cities. Both of their comprehensive plans mention designing supportive policies, upgrading infrastructure, and offering additional services to industrial users in their specialized industrial zones, but it is unclear whether either has implemented these new policies.

A popular strategy for cities beyond simply making zoning more stringent is adding new process requirements for redevelopment. What is interesting for the sub-sample of cities using greater process requirements is the use of approvals at at multiple levels of government even beyond the city. Minneapolis, for example, ultimately requires approval from its regional planning agency for proposed redevelopment in its new employment districts, while Baltimore requires approval from the state's Port administration. For cities that do not have a strong, or formalized, regional planning structure this is a way for cities to have regional, or state, goals weigh on local decisions. In effect, this is a strategy to neuter local political sway and to blunt the aspirations of developers looking at industrial districts for conversion.

Beyond increased restrictions or more onerous process, a small array of cities are also directly linking these new protective land-use policies to greater economic development strategy. In the case of New York, the city's IBZs are primarily a vehicle for steering subsidies to industrial users in addition to providing greater tenure security to users. Other cities mention increasing spending on supportive infrastructure for industrial users and encouraging workforce development policies to better match employers with employees. It is still too early in most of these cities to see whether they will be successful in these endeavors but they are interesting examples of explicitly linking land-use and economic development policy.

\section{Conclusion}

There is a general consensus that manufacturing is dying in the United States and that what little manufacturing is left certainly does not have a place in cities. But while commentators discuss the rise of the "post-industrial" they ignore the fact that manufacturing is still a non-trivial part of city, and regional, economies employing thousands of people in each city and are disproportionate contributors 
to GDP. Additionally, the new demands of advanced manufacturing that require extensive research and development support, fast prototyping capabilities and extensive cooperation between designers and manufacturers make cities the preferred locations for new manufacturing establishments and employment. Given the intense pressure to convert industrial parcels to non-industrial uses in many strong, and some weak market, cities it is a welcome development that cities are treating their remaining industrial land as an asset and protecting it. These strategies, if linked with more proactive economic and workforce development policies, can help to seed new rounds of urban manufacturing firm growth and help US cities, and firms, remain innovative and growing.

Beyond the economic development potential of these policies, the growing embrace of these policies challenges greater notions of what the "post-industrial" US city is supposed to look like and the development politics therein. Land-use policy decisions in the putative "post-industrial" city is too often built on the assumption that urban industry is dead or dying (Ferm and Jones 2016; Gospodini 2006). But recent scholarship highlights the direct role that cities play in their own deindustrialization through their development priorities and land-use policies that favor redeveloping already occupied, productive industrial districts into new commercial and residential centers, whether the justification is to simply increase local property tax revenue or is reflective of the flawed implementation of a Smart Growth plan (N. G. Leigh and Hoelzel 2012; Rast 2001; Wolf-Powers 2005). Cities are rejecting the conventional conventional wisdom that the best land-use is the use that maximizes property values and that industry has no place in the city because it is dying, obsolete, or environmentally harmful. While this is the case regarding industry in many cities, it is certainly not a universal case and it is not a sufficient enough reason for cities enthusiastically redevelop healthy industrial districts.

These protective policies potentially signal, then, a transformation in the way that city planners understand the role that industry and manufacturing play in their cities as well as the rejection of the selective application of "highest and best use" economic reasoning that justifies the conversion of scarce industrial land but is not applied to areas of cities dominated by single family zoning. Additionally, the linking between these land-use policies and greater economic development policy signal a positive development in explicitly joining economic development and land-use priorities where before they may have been at odds. While these policies are still very new, they call out for greater attention as they potentially signal a radical shift in urban land management in the US large city.

\section{References}

Bernhardt, Annette, and Paul Osterman. 2016. "Organizing for Good Jobs Recent Developments and New Challenges." Work and Occupations, January, 
0730888415625096 . doi:10.1177/0730888415625096.

Byron, Joan, and Nisha Mistry. 2011. "The Federal Role in Supporting Urban Manufacturing." The Brookings Institution. http://www.brookings. edu/ /media/Research/Files/Papers/2011/4/urban\%20manufacturing\%

20mistry\%20byron/04_urban_manufacturing_mistry_byron.PDF?_hstc= 753710.cb9d9e877dff221e238e3228e776cfd5.1461273525304.1461273525304. $1461273525304.1 \& \_\mathrm{hssc}=753710.1 .1461273525304 \& \_\mathrm{hsfp}=2755693145$.

Chapple, Karen. 2014. "The Highest and Best Use? Urban Industrial Land and Job Creation." Economic Development Quarterly, August, 0891242413517134. doi:10.1177/0891242413517134.

City of Baltimore. 2017. "Article 32- Zoning." June 5. http://ca.baltimorecity. gov/codes/Art\%2032\%20-\%20Zoning.pdf.

City of Chicago. 1988. PMD, Planned Manufacturing Districts. https:// chicagocode.org/17-6-0400/.

City of San Jose. 2007. "Approved Framework for Preservation of Employment Lands for the City of San Jose." City of San Jose.

Dempwolf, C. Scott. 2010. "An Evaluation of Recent Industrial Land Use Studies: Do Theory and History Make Better Practice." Retrieved August 28: 2010. http://www.terpconnect.umd.edu/ dempy/docs/Review\%20of\%20Industrial\%20Land\%20Use\%20Studies\%20C.

Ferm, Jessica, and Edward Jones. 2016. "Beyond the Post-Industrial City: Valuing and Planning for Industry in London." Urban Studies, October, 0042098016668778. doi:10.1177/0042098016668778.

Fitzgerald, J., and N. G Leigh. 2002. Economic Revitalization: Cases and Strategies for City and Suburb. Sage Publications, Inc.

Gospodini, Aspa. 2006. "Portraying, Classifying and Understanding the Emerging Landscapes in the Post-Industrial City." Cities 23 (5): 311-30. doi:10.1016/j.cities.2006.06.002.

Kalleberg, Arne L. 2011. Good Jobs, Bad Jobs: The Rise of Polarized and Precarious Employment Systems in the United States, 1970s-2000s. Russell Sage Foundation. http://books.google.com/books?hl=en\&lr=\&id=_LAxvyG_ eGcC\&oi $=$ fnd \&pg $=$ PR13\&dq $=$ good + jobs + bad + jobs\&ots $=q V c \_K o 0 Y 7 O \&$ sig= $\mathrm{vPx} 3697 \mathrm{ycGtQQFW}-4-$ Tnhm5bUAg.

Leigh, Nancey Green, and Nathanael Z. Hoelzel. 2012. "Smart Growth's Blind Side: Sustainable Cities Need Productive Urban Industrial Land." Journal of the American Planning Association 78 (1): 87-103. doi:10.1080/01944363.2011.645274.

Leigh, Nancey, Nathanael Z. Hoelzel, Benjamin Kraft, and C. Scott Dempwolf. 2014. Sustainable Urban Industrial Development. Planning Advisory Service 577. APA Planning Advisory Service.

Lester, Thomas W., Nikhil Kaza, and Sarah Kirk. 2013. "Making 
Room for Manufacturing: Understanding Industrial Land Conversion in Cities." Journal of the American Planning Association 79 (4): 295-313. doi:10.1080/01944363.2014.915369.

Rast, Joel. 2001. "Manufacturing Industrial Decline: The Politics of Economic Change in Chicago, 1955-1998." Journal of Urban Affairs 23 (2): 175-90. doi:10.1111/0735-2166.00082.

Wolf-Powers, Laura. 2005. "Up-Zoning New York City's Mixed-Use Neighborhoods Property-Led Economic Development and the Anatomy of a Planning Dilemma." Journal of Planning Education and Research 24 (4): 379-93. doi:10.1177/0739456X04270125. 